\title{
A Population Study of the Cave Beetle Ptomaphagus loedingi (Coleoptera; Leiodidae; Catopinae)
}

by

\author{
Stewart B. PECK*
}

\section{INTRODUCTION}

Caves are generally regarded as stable environments, and fluctuations within populations of cave-inhabiting animals would not be expected, or would be expected to be slight. However, various studies have shown that the environmental conditions of caves do change (Barr, 1967; 1968; Barr and Kuehne, 1971; Poulson and White, 1969). How these changes affect cave faunas is poorly known. Very few populations of cave-inhabiting insects have been observed for a sufficient period of time to document changes (if any) in population densities and their causes

To contribute data on the seasonal abundances of a cave insect in different cave habitats, a population was studied of the common troglobitic (obligately cave-inhabiting) scavenging beetle Ptomaphagus loedingi loedingi Hatch in Madison County, Alabama from 1965 to 1973.

\section{THE STUDY SITE}

Barclay Cave, on the northern outskirts of Huntsville, Madison County, Alabama was chosen as a study cave because it was convenient, was known to have a Ptomaphagus beetle fauna, and was a small enough cave that varying ecological and environmental factors could be kept to a minimum.

The general features of the cave are shown in figure 1 . The cave entrance in located at the side of an east-facing limestone sink, on the flanks of King Mountain. From the entrance the cave runs west for 54 meters. A spring of water keeps the back of the cave continually wet.

The cave floor is varied. The entrance is a mixture of large rocks, boulders, and gravel. The whole of the level floor of the cave is a composite of gravel and compacted silt. A relatively small area, just inside the entrance, to the south, is composed of loose silt over a multiple terrace of wide travertine platforms.

Organic debris, including that deposited by man, is generally scattered throughout the cave. The debris and trash were washed into the cave from the entrance sink during vernal rainstorms. During such periods of flood, the water fills the cave almost to the level of the silt terraces.

*) Department of Biology, Carleton University, Ottawa, Ontario, Canada. 


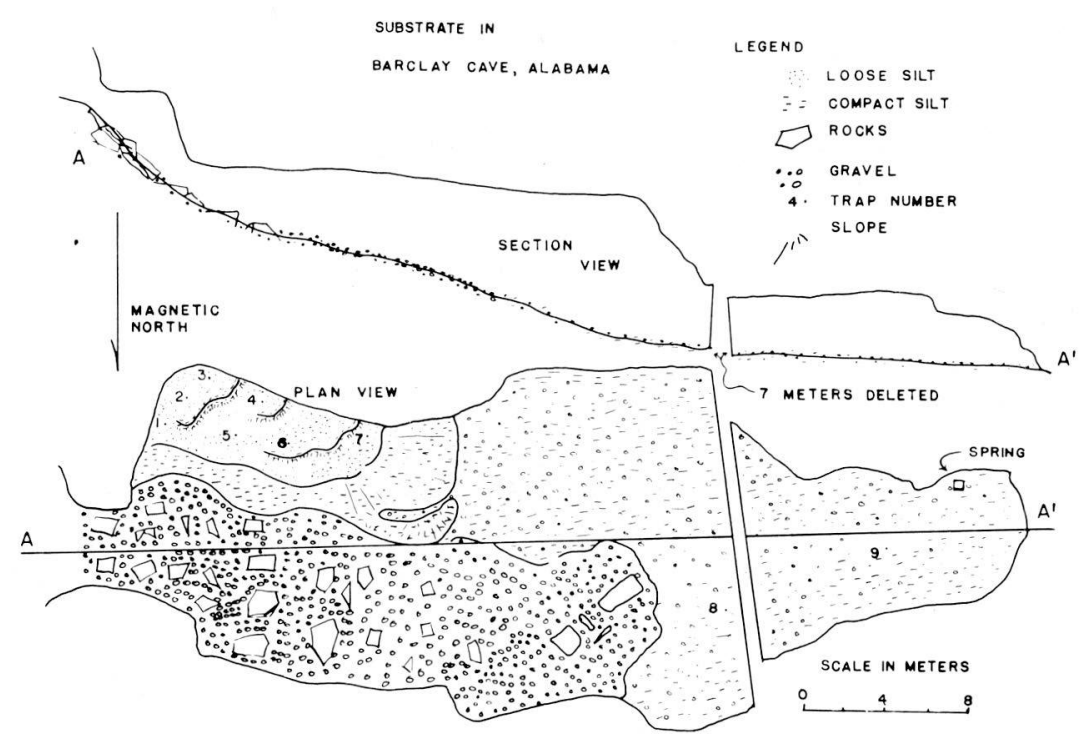

A - Fig. 1. Map of plan and section of Barclay Cave, Huntsville, Alabama, showing substrate composition, and location of pitfall traps.

The small size and unattractive nature of the cave renders it relatively free of visitation by man. The cave has been designated as a "Fallout Shelter" by the local Civil Defense agency and has a calculated capacity of 78 people. The small yet spacious nature of the entire cave is summarized by the fact that when the trees at the entrance are in a leafless condition, the early morning sun lights the cave so that its end can be safely reached without artificial illumination.

During the period of investigation in 1965, weekly visits were made to the cave to take wet and dry bulb temperatures on a Taylor hygrometer. The data were collected at an elevation of one meter above the cave floor at two sites; the back of the cave near the spring, and in the area of the loose silt. The temperatures remained steady at $14.5^{\circ} \mathrm{C}$ in the summer. Two readings from December showed the marked cooling (to $10^{\circ} \mathrm{C}$ and $7{ }^{\circ} \mathrm{C}$ ) experienced by a small cave in the winter. During this season, the colder and more dense air sinks into the cave from the entrance. The cold air displaces the warm air and forces it from the cave.

The relative humidities recorded in Barclay Cave throughout the summer were found to be constantly at or above $97 \%$ in the cave, both front and back. Though the air at waist level was $97 \%$ saturated, it can be assumed that the beetles living on the moist silt cave floor practically were in a saturated atmosphere.

In relative humidities, the December readings again showed a variance from the summer conditions. Fluctuations between $85 \%$ and $93 \%$ were recorded over a ten day span. The relative humidity drop is a reflection of the colder air occupying the 
cave. While the cold winter air persists in the cave, heat is radiated from the surrounding wall rock, and the air warms up. The warming of the air lessens its density and it rises and may be expelled from the cave. The warming air draws moisture from the cave walls and floor and carries the moisture with it out of the cave. In addition, in early and mid-winter only a small amount of percolating water is available in the cave wall rock. These factors combine to dry the cave and the substrate in the winter months. The dry winter conditions were verified at a glance by the loose silt of the terraced area near the entrance. During mid and late summer the soil was moist and had a dark-brown appearance. The winter observations showed the soil to be dry and crumbly in texture and gray in color.

\section{TRAPPING EXPERIMENTS IN BARCLAY CAVE}

Cave Ptomaphagus beetles are generally secretive in habit. They occur most commonly under rocks and debris and in cavities in gravel along subterranean streams. The beetles are seldom found actively crawling about the cave. They usually move only after being disturbed. These factors, in addition to their brownish color, which blends with most cave substrates, makes hand collecting difficult. Baiting and trapping often show the beetles to be truly abundantwhereas hand-collecting can secure only a few specimens. Previous work had shown that the beetles come to several different baits (Peck, 1973). Rotten meat and fruit, and soft odorous cheeses have been used with success. An epigean species, $P$. consobrinus, comes to traps in Florida baited with a scarab beetle attractant of malt syrup with a touch of proprionic acid (Howden, 1955:160).

\section{PURPOSE}

It was expected that many aspects of seasonality and ecological preferences of the beetles might be shown by trapping in Barclay Cave. (1) By placing traps at different areas in the cave, an idea might be gained of substrate and microclimate preferences. (2) By utilizing different baits in a relatively small area, the relative numbers of beetles in the differently baited traps should show the relative appeal of the different baits. (3) Differences in abundance of males, females and larvae throughout the trapping period might reflect the seasonal population structures.

\section{PROCEDURE}

In 1965, traps were set on July 13 at different stations in the terraced area. On July 26 traps were set in the middle of the cave-room, and at the back of the cave. The positions are shown with the station numbers in figure 1. The traps have been described by Peck (1973) and Poulson and Culver (1969). Each week the traps were checked, their contents removed, the bait replaced, and fresh Galt's solution was 
put in the trap. The solid baits were about a two centimeter diameter sphere. The liquid baits were about three $\mathrm{ml}$ of an organic acid on a cotton wad wrapped in cheese cloth. The meat bait was decayed hamburger. The banana was used fresh. The cheese bait was limburger. The trap contents were sorted, sexed and tabulated the day the trap was picked up. From August 17 to September 1 several baits at some of the stations were switched to avoid the possibility of gaining erroneous information from beetle accumulations induced by the trapping itself within the small boundaries of the terrace area. This experiment was terminated on September 1 .

\section{RESULTS}

The weekly checks of the traps continually showed some ten taxa to be regularly attracted and trapped. In no environment is an organism apt to be free of reactions from its neighbor organisms, but for the sake of simplicity, the quantitative and qualitative data on trap contents are presented only for Ptomaphagus. Table 1 summarizes this information. The results will be discussed with respect to the three fundamental problems as stated in the purpose of this multiple experiment.

(1) Substrate and microenvironment preferences. Stations 1 to 7 , on the terraces, are grouped as a unit. They were positioned in an area of fairly loose soil which retained a qualitatively uniform moisture content throughout the study period. The organic nature of the soil was evident in its dark color. Bits of plant debris lay scattered irregularly throughout the area. The greatest distance between traps was about three meters. The entire area was only ten meters long by four meters wide. This area yielded 850 adult and larval beetles in seven weeks of trapping at the seven stations. The 850 beetles are a significant part of the total of 897 for the entire cave.

Stations 8 and 9 are grouped as a second substrate type. The stations were located in the cave-room proper. The substrate consisted of a fairly compact muddy silt. The soil appeared to be as organic in content as that in the terrace area. This region is subjected to occasional flooding. The two trap stations yielded 47 adult and larval beetles in five weeks of trapping. Station 9, at the back of the cave, yielded no beetles, so the catch was solely that of trap 8:

A quantitative idea of substrate preference is gained if the number of beetles per substrate is divided by the number of traps operated per week per substrate type. The terraced area gave 850 beetles per seven traps operated for seven weeks, or 850 beetles/49 trap-weeks. The cave-room stations gave 47 beetles per two traps operated for five weeks, or 47 beetles/10 trap-weeks. Thus group 1-7 gave 17.3 beetles/ trap-week. Group 8-9 gave 4.7 beetles/trap-week. Obviously there is a greater population around stations 1-7 in the terraced area.

If the effects of the baits are considered, an even more dramatic preference for area 1-7 is obtained. As will be shown later, the organic acids did not have an attractant effect. If we only consider the captures from the traps which were not acid-baited, there were 845 beetles caught in 35 trap-weeks, or 24 beetles/trap-week for area 1-7. 
POPULATION STUDY OF PTOMAPHAGUS LOEDINGI

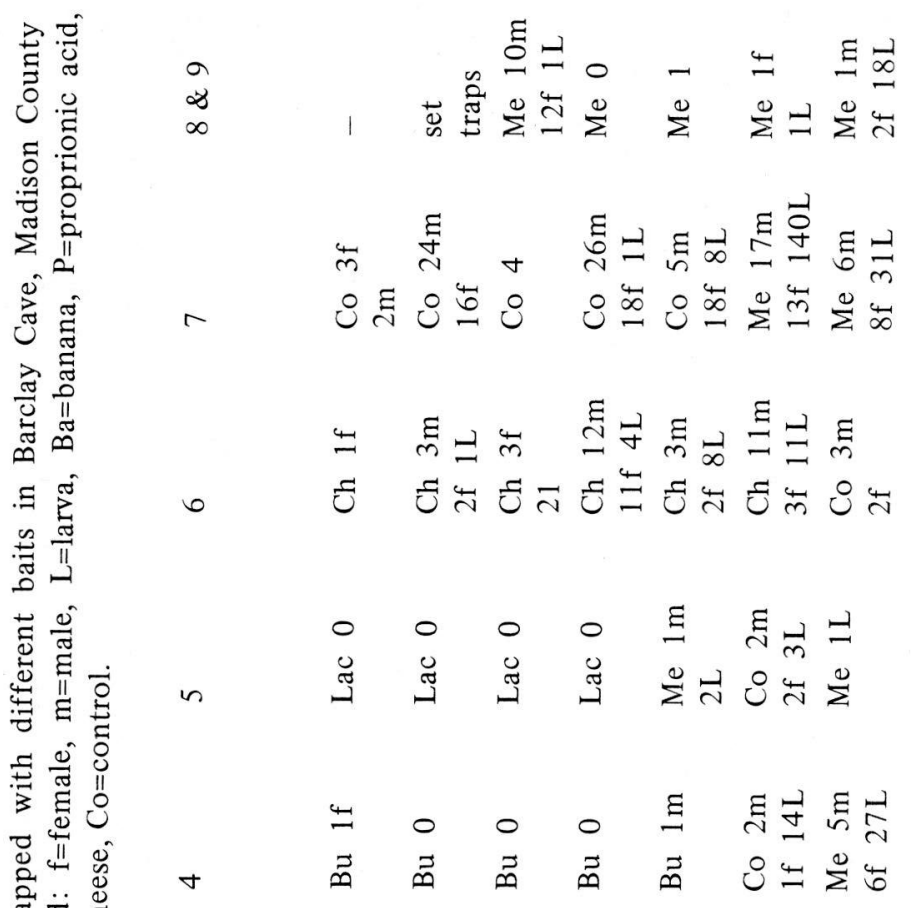

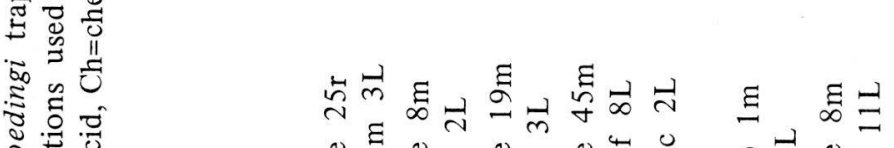

过

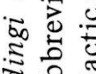

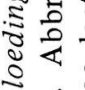

\&

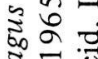

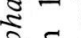

₹.

ई

党 常

虫 $\frac{0}{\frac{1}{2}}$

تี

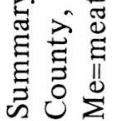

恋

要

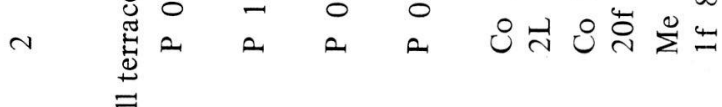

क

㟧

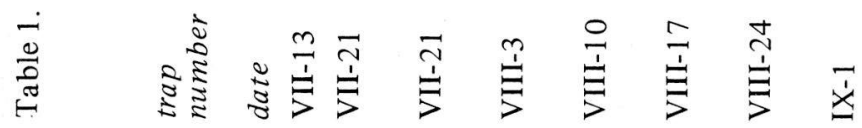


Table 2. Bait Preference Experiment in Barclay Cave, Alabama, 1965. Data only from stations 1-7.

$\begin{array}{ll}\text { total beetles/total } & \\ \text { number of traps times } & \text { beetles/trap-week } \\ \text { number of weeks bait } & \\ \text { used at trap } & \end{array}$

$\begin{array}{lll}\text { meat } & 500 / 13 & 38.5 \\ \text { control } & 235 / 12 & 19.5 \\ \text { cheese } & 77 / 6 & 12.8 \\ \text { banana } & 33 / 4 & 8.25 \\ \text { butyric acid } & 2 / 5 & 0.4 \\ \text { lactic acid } & 2 / 5 & 0.4 \\ \text { proprionic acid } & 1 / 4 & 0.25\end{array}$

A more valid comparison is between only meat-baited traps in area 1-7 and meat-baited traps in area 8-9. Thus 500 beetles per 13 trap-weeks yields 38.5 beetles/trap-week when meat-baited in area 1-7. This figure constrasts strongly with 4.7 beetles/trap-week when meat baited at stations 8-9.

(2) Bait Preference. The uniform area presented by the terraced section of Barclay Cave offered a suitable area to determine which baits were more attractive to the beetles. The data from stations 8 and 9 are not included in the calculations. The results, derived from table 1 , are presented on table 2. Males, females and larvae are combined for each trap-week collection. The data show that bait of decayed hamburger has an attracting value of 38.5 beetles per trap-week. The next best baits were cheese and banana with respective values of 12.8 and 9.25 beetles/ trap-week. The three acids yielded from 0.4 to 0.25 beetles/trap-week. The most surprising figure is that of 19.5 beetles/trap-week for the unbaited control trap. This figure allows two alternative viewpoints for the examination of the data of the baited traps.

The first possibility is that though the trap was thought to be "unbaited", the Galt's solution had an attractive effect on the beetles. If so, it was half as attractive as the hamburger, and one and one-half times more attractive than the cheese. The second possibility is that the Galt's solution has a neutral attractant value. If so, the contents of the control trap demonstrate the overall accidental tendency of the beetles to wander and become trapped. If the control represents accidental trapping, the meat bait still showed an attractant value, but all figures lower in value than the control figure showed an avoidance of those traps and baits. Hence, in this situation, cheese and banana, as well as the acids were repellants. Since the beetles come to cheese and banana when used without traps, it is unlikely that banana or cheese should be considered as repellants, and it must be that the control trap with only Galt's solution was attractive.

(3) Seasonal Structure of the Population. A period of only two months is far 
from sufficient for any study of population fluctuation. Nevertheless, some trends in this population were shown by the trapping. These data, derived from Table 1 are presented on figure 2 and table 3. Weekly variances exist between the ratio of the sexes captured. Only in the first two weeks is the imbalance large, and these values are reversed later. The summation shows a 51\% male composition and $49 \%$ female composition, in a total of 534 sexed beetles. The sexes of an additional five were not determined and are not included in the calculations.

The low number of larvae at the beginning may reflect little reproductive activity in the time before the study began. The gradual rise and the culmination in 195 larvae trapped in one week reflect a natural rise in reproductive activity in the first half of August. The increase in adults from VIII-17 to VIII-24 may reflect an increase in emergences of young adults from the pupal cells, but the low numbers of pale teneral (newly emerged) beetles does not support this.

The trapping did not show an appreciable reduction in the population when the experiment was terminated. Little is known about the effects of excess collecting of cave populations, but it would appear that at the termination of the experiment on IX-1 the population was at about the same level as at the initiation of the experiment on VII-13. The possibility does exist that the summer buildup of the population is mandatory to ensure its survival over the winter months. The removal of almost 900 specimens then could seriously affect the population's survival capacity. Only continued investigations into the Barclay Cave population would give an answer to this question.

The terrace area of Barclay Cave is about 10 meters long and 4 meters wide. During the seven week-trap experimentation period, 507 adult beetles were taken from this some 40 square meter area. Of all the beetles, only a few were teneral (recently emerged from the pupal cell). It would appear that the population was not being replenished by young individuals as the trapping continued. Immigration into the terrace area from the cave room does not seem likely in view of the low

Table 3. Weekly distributions of male, female and larval Ptomaphagus 1. loedingi trapped in Barclay Cave, Alabama, 1965. Data from all stations.

$\begin{array}{lccccc}\text { date } & \text { males } & \text { females } & \text { larvae } & \begin{array}{l}\text { total } \\ \text { adults }\end{array} & \begin{array}{l}\text { no. } \\ \text { tenerals }\end{array} \\ \text { VII. } 21 & 13 & 38 & 5 & 51 & \\ \text { VII. } 26 & 47 & 22 & 3 & 69 & \\ \text { VIII. } 3 & 30 & 28 & 6 & 58 & \\ \text { VIII. } 10 & 86 & 88 & 20 & 174 & 2 \\ \text { VIII. } 17 & 12 & 20 & 26 & 32 & \\ \text { VIII. } 24 & 58 & 45 & 195 & 103 & 2 \\ \text { IX-1 } & 26 & 21 & 102 & 47 & 1\end{array}$


population density found in the room. And immigration from elsewhere is unlikely in view of the closed wallrock boundaries on the backside of the terraces. The remaining source of the beetles must be from those remaining in the loose soil substrate of the terraces themselves. Other investigations have shown that the beetles may have an adult life-span of much more than one year. If we assume that those beetles captured at the end of the summer were adults at the beginning, we arrive at a population density of 507 adults in the 40 meter square area under discussion. This is a figure of 12.5 beetles per square meter of cave floor.

The initial assumptions in deriving a density of 12.5 beetles per square meter may yield too high a figure. But, since the population was not extinguished, the terrace still bore a reservoir of adults, and hence the density of 12.5 may not be high enough. At any rate, this figure demonstrates a remarkably high density for cave animals generally considered to be uncommon, and highly dispersed in occurrence.

Cause of the fluctuation. The threefold increase in adult abundance in early August is believed to have been caused by cavesoil moisture conditions. No quantitative measures were made, but the cave soil was observed to be comparatively dry at the beginning of the trapping program in July. General weather conditions had been unusally dry in Madison County throughout the spring and early summer of 1965. Heavy rains occurred late in July and early August. On August 10, when the largest adult beetle catch occurred, the cave soil had become notably more moist. My interpretation is that adults that were inactive and hiding in the cave soil crumbs (not in pupal cases) became active with the onset of favorable moisture conditions.

Reproductive seasonality. Figure 2 shows that very few larvae were trapped in the first five weeks of the study. If a histogram of larval head capsule width can be used to separate larvae into three instars (figure 3, prepared from all larvae caught in the cave), then the presence of all three instars (figure 4) in these weeks shows that reproduction is probably continuous, even under unfavorable conditions. The large burst of larvae (fig. 2) caught on August 24, especially in the light of the fact that most were first instar larvae (figure 4) shows that the abundant adults two weeks earlier had been reproductively mature and active before capture. The larval pulse following the adult pulse by two weeks is expected in the light of information gained later. In laboratory culture at $15^{\circ} \mathrm{C}$ the eggs ot this beetle hatch in 10 to 13 days and the larvae pass through the first two instars in 4.5 and 5.2 days respectively (Peck, 1967, and personal data).

(4) Mark Recapture studies. Population estimates were later made to study the effect of the 1965 trapping on the population. A mark-recapture census was made on several occasions by marking with a small dot of "Testors Pla" paint the adults attracted to bait in a 24 hour period. Laboratory cultures showed that the paint would adhere to the beetles for several months. After marking, the bait was removed, and the beetles allowed to distribute themselves for a week. Then the same sites were again baited and all adults collected 24 hours later, examined and released. The census data is presented in table 4. Between August 1967, and September 1968 , the cave flooded to such an extent that only the upper terraces were not 
under water. This may have affected the population. A census attempt in 1971 failed because a different type of marking paint was used, but it was observed to flake off of the beetles in less than a week.

The populations of active adult beetles were found to be low, compared to the apparent population of 1965, in four censuses in 1967 and 1968. The population of active adult beetles had recovered to a level similar to that of 1965 by 1972 and 1973 , seven and eight years later.

(5) Other census methods. Attempts in 1967 were not successful in obtaining a comparison census by other methods. A one meter square of cave soil was marked off as a quadrat with flypaper to obtain an estimate of beetle movements and activity in attempting to walk out of or into the quadrat. Only immature crickets and phorid flies were captured. A third census technique was to extract with Berlese funnels the fauna from the soil of two quadrats each a meter square. It was expected that an adult population which is present but inactive and hiding in the soil could be recovered. No beetles were obtained with this technique either.
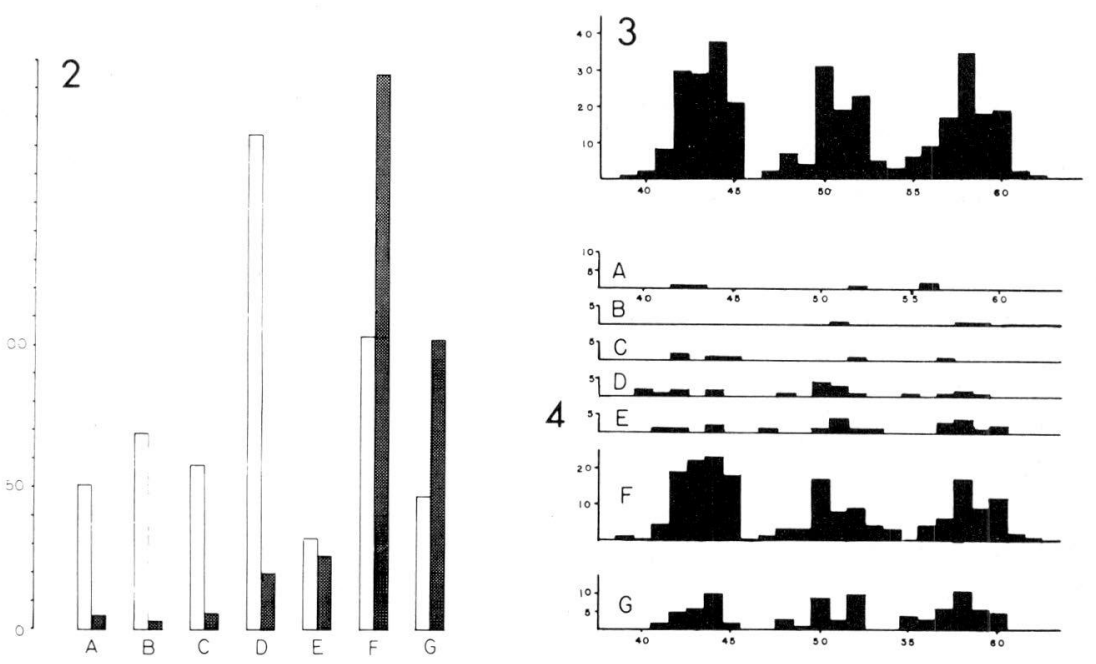

B - Fig. 2. Numbers of adult (open bar) and larval (dark bar) Ptomaphagus loedingi loedingi captured at weekly intervals in pitfall traps in Barclay Cave, Madison County, Alabama, in 1965. The end of each trapping period is as followd: A, 21.vii. B, 26.vii. C, 3.viii. D, 10.viii. E, 17.viii. F, 24.viii. G, 1.ix.

- Fig. 3. Combined distribution of widths of head capsules of larvae trapped in Barclay Cave. The three groups represent the presence of three larval instars, a conclusion verified by laboratory cultures of the species. Abcissa in ocular micrometer units where 1 unit = $0.013 \mathrm{~mm}$.

- Fig. 4. Distribution, at weekly intervals, of widths of head capsules of larval Ptomaphagus loedingi loedingi caught in traps in Barclay Cave in 1965. Time periods as in Figure 2. 
Table 4. Estimates of the population of active adult Ptomaphagus loedingi on terraces of Barclay Cave, using the simple Lincoln Index (mark recapture method).

$\begin{array}{lccc}\text { date } & \begin{array}{l}\text { total } \\ \text { captures }\end{array} & \begin{array}{l}\text { marked } \\ \text { recaptures }\end{array} & \begin{array}{l}\text { pop. size } \\ \text { estimate }\end{array} \\ \text { 25. vi. } 67 & 18 & - & 132 \\ \text { 2. vii. } 67 & 22 & 3 & \\ \text { 19. vii. } 67 & 8 & - & 28 \\ \text { 28. vii. } 67 & 7 & 2 & \\ \text { 12. viii. } 67 & 7 & - & 37 \\ \text { 20. viii. } 67 & 15 & 3 & \\ \text { 1. ix. } 68 & 12 & - & 66 \\ \text { 12. ix. } 68 & 11 & 2 & 506 \\ \text { 10. v. } 72 & 46 & - & \\ \text { 19. v. } 72 & 22 & - & 813 \\ \text { 7. vii. } 73 & 75 & 13 & \\ \text { 13. vii. } 73 & 141 & & \end{array}$

(6) Cold Spring Cave population density. An independent population density study was conducted in Cold Spring Cave, Madison County, Alabama. The cave consists of a debris covered slope extending from the entrance to within ten feet of the cave end. This last ten feet is flat and floored with sand and a few rocks, lying at the bottom of a solution dome. A large P. loedingi loedingi population was thought to inhabit the cave because previous baiting in the cave had attracted an estimated 300 adult beetles. From August 21 to September 14, 1968, ten visits were made to the cave, collecting and counting all adults at four carrion bait stations on (but near the bottom of) the debris slope, and four carrion bait stations on the flat ground at the cave end. A total of 1,673 adults with many tenerals was captured. Individuals were never collected twice because all captured adults were placed in a plastic box in the cave and held to be released at the end of the study. Most of the beetles were inhabiting the area of the sterile looking sand at the cave end. Only 144 came from the baits on the seemingly food-rich entrance slope. The remaining 1,529 came from the cave end, with a floor area of nearly 11 square meters. This gives a very high density of 139 adult beetles per square meter. The population was not exhausted in the study because on the last day 87 adults were collected. An easy explanation for such large numbers would be that the beetles were immigrating to the bait from other sections of the cave. I discount this possibility. The baits on the entrance slope showed a much lower population there, and it would not seem likely that individuals would ignore nearby baits and go to distant ones. The possibility is also unlikely that the beetles were coming to the baits from areas deeper in the cave. The sides and end of the cave are vertical rock walls with no small holes 
allowing connection to more cave. The only exception is that at one side is a small irregular pile of rocks into which excess water drains. This drain may have contact with a region harboring a large enough population to account for many or most of the 1,529 adult beetles. Nevertheless, in conclusion, although a population density of 139 adults per square meter may be too high, the fact is that 1,673 beetles were attracted to eight baits in less than a month in a cave with a measurable length of only 60 feet $(20 \mathrm{~m})$.

Of these 1,673 beetles, about 200 were kept for laboratory studies, and about 700 perished from drowning when one holding container was flooded by a sudden rain storm. The other 700 estimated beetles were released back into the cave population. Later, similar baiting at the same sites in Cold Spring Cave found very few beetles. Carrion baits from 12 to 22 August, 1971, attracted only six beetles, in very wet conditions. On 11 to 17 May, 1972, only two adults were attracted to carrion baits, again under very wet conditions. Similar baits from 6 to 13 July, 1973, attracted 73 adults from the cave floor and at the bottom of the entrance slope. No beetles were attracted to baits on the entrance slope itself. In conclusion, this cave, which had a very large population in 1968, was found to have a considerably smaller population four and five years later.

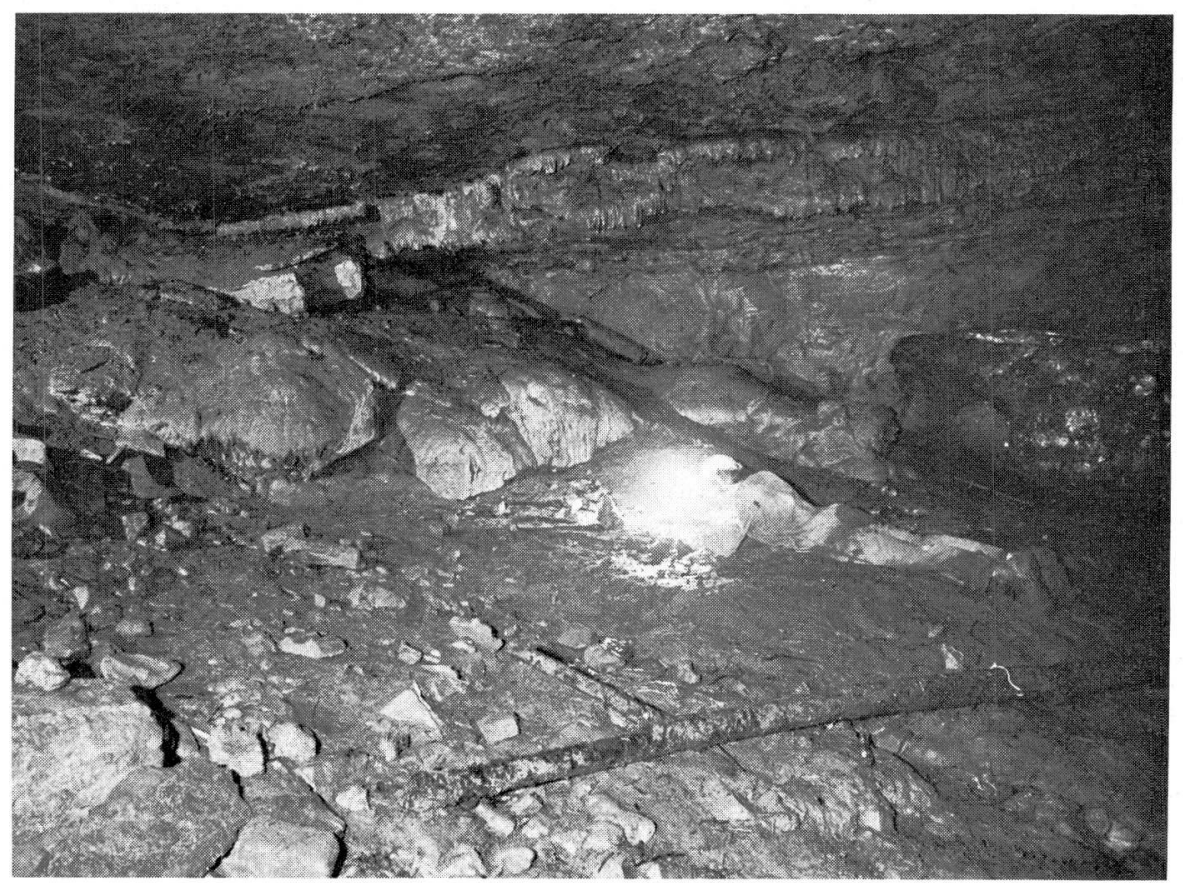

C. - The terraced study area in Barclay Cave. The entrance is $10 \mathrm{~m}$. to the left. The figure is Cammeron Laing searching for beetles at bait. 


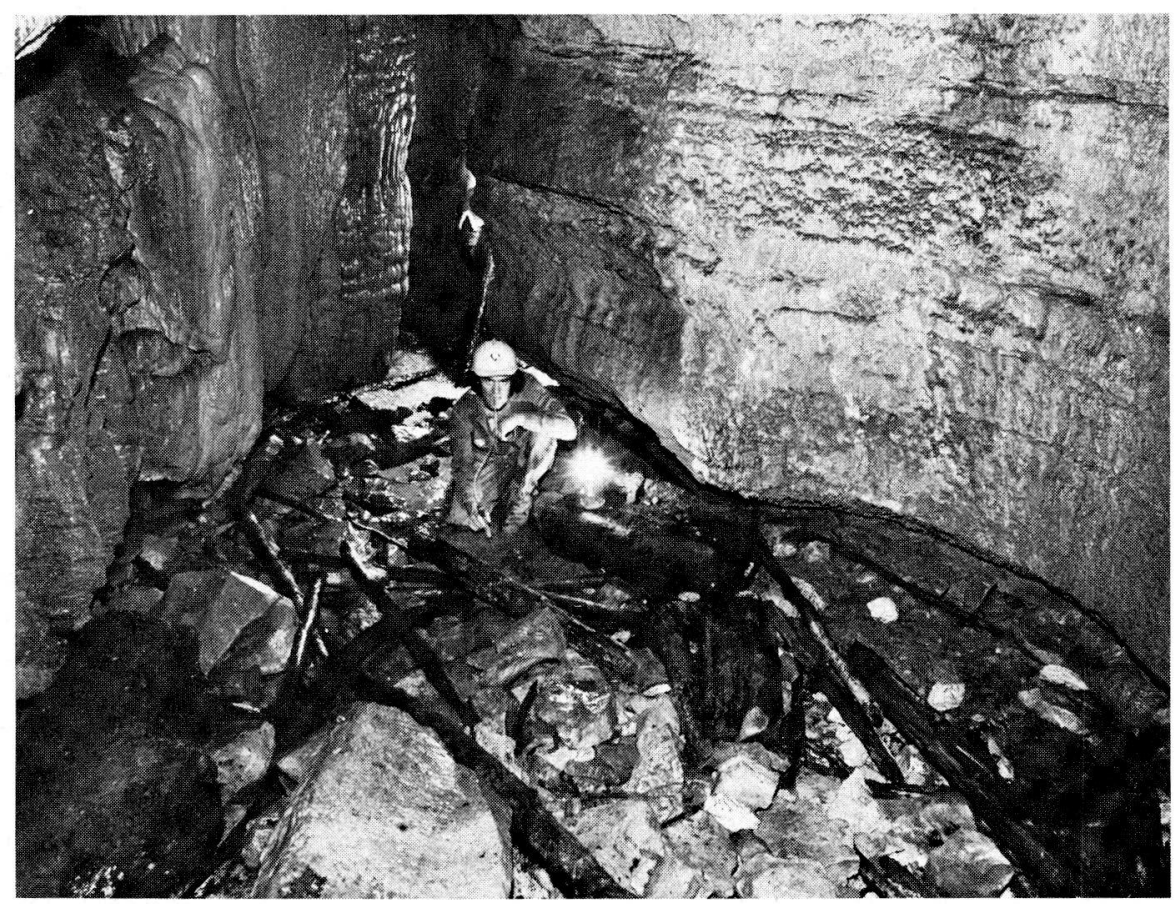

D. - End of Cold Spring Cave where $P$. loedingi was found to have a density of 139 adults $/ \mathrm{m}^{2}$ in 1968.

\section{CONCLUSIONS}

The above ecological observations on Ptomaphagus beetles are an imperfect study. Full understanding will come only by carefully following several populations over a long period of time. This will be difficult for someone such as myself who is at an institution in the north, at a great distance from the cave fauna of the southeast. Additionaly, these beetles are only one member of many cave communities. I have not adequately examined the relationship of Ptomaphagus to other community members and to various environmental factors as has been done in the study in Flint Ridge Cave in Kentucky by Poulson and Culver (1969).

Lastly, faunal census techniques other than trapping will have to be employed. Censusing at bait stations is preferable to trapping because traps may exterminate the fauna of a small cave. The use of traps is justifiable only under a few and special circumstances such as in Barclay Cave and in Flint Ridge Cave. An earlier statement of mine (Peck, 1967b) implied that trapping in Barclay Cave had not upset popula- 
tion equilibria. I now feel that this is incorrect, and that the Barclay Cave fauna was drastically disturbed. This new conclusion on the harmful effects of trapping is based upon the low population estimates obtained for many years after 1965, and in view of the long life span and low reproductive rates of the adults. These factors which limit the ability of the beetle population to recover from trapping are probably true for most if not all other troglobitic arthropods.

\section{ACKNOWLEDGEMENTS}

Mr. Alan Fiske is thanked for his field assistance in 1967. Dr. and Mrs. Walter B. Jones of Huntsville graciously provided a headquarters from which to conduct the field work. Financial support came from NSF grants GB 3167 and GB 7346 to the Evolutionary Biology Committee, Harvard University, Professor Reed C. Rollins principal investigator.

\section{SUMMARY}

Baited pitfall traps were used in Barclay Cave, Alabama, in 1965 to study a blind Ptomaphagus beetle population. A $40 \mathrm{~m}^{2}$ area in the cave yielded $95 \%$ of the 897 adult and larval beetles trapped in the cave at 9 stations. This represented a population density of about 13 beetles $/ \mathrm{m}^{2}$. Tests of different baits showed decayed meat to be the most attractive. Adults were most abundant in mid-August when substrate conditions were moist, were reproductively active, and were not newly emerged from pupal cells. Larvae were most abundant in late August. The population was studied by mark-recapture methods for 8 years after the pitfall trapping, and it was judged to have recovered to former densities after about 6 to 8 years. The use of traps which kill cave invertebrates is not encouraged for most future cave ecology studies.

Population densities of beetles at baits in Cold Spring Cave were found to be 139 adults $/ \mathrm{m}^{2}$ in 1968 , and to much lower in three later years.

\section{RESUME}

En 1965, des pièges avec appât furent utilisés dans la grotte de Barclay en Alabama, afin d'étudier une population du Coléoptère aveugle Ptomaphagus. Une surface de $40 \mathrm{~m}^{2}$ a fourni $95 \%$ des 897 adultes et larves piégés dans 9 stations de la grotte. Ce qui correspond à une densité de population d'environ 13 par $\mathrm{m}^{2}$. Des essais faits avec différents appâts ont montré que ce qui attire le plus est la viande avariée. A la mi-août, lorsque le substrat est humide, les adultes sont plus abondants, ils se reproduisent et sont sortis des pupes depuis un certain temps déjà. Les larves sont plus abondantes vers la fin août. Au cours des huit années qui ont suivi le piégeage, la population a été étudiée par des méthodes de recapture après marquage et on peut estimer avoir retrouvé les densités initiales au bout de 6 à 8 ans. L'utilisation 
de pièges qui tuent les invertébrés cavernicoles n'est pas encouragée dans des études futures de l'écologie des grottes.

Les densités de population des coléoptères sur les appâts de la grotte Cold Spring ont été de 139 adultes par $\mathrm{m}^{2}$ en 1968 et ont beaucoup baissé au cours des trois dernières années.

\section{REFERENCES}

Barr, T. 1967. Observations on the ecology of caves. Amer. Nat., 101 (922): 475-492.

Barr, T. C. 1968. Cave ecology and the evolution of the troglobites, in: Evolutionary Biology, T. Dobzhansky, M. Hecht, W. Steere eds., v. 2: pp. 35-102. Appleton-Century-Crofts, New York.

Barr, T. C., Jr. and R. A. Kuehne. 1971. Ecological studies in the Mammoth Cave system of Kentucky. II. The ecosystem. Ann. Spéléol., 26: 47-96.

Howden, H. F. 1955. Biology and taxonomy of North American beetles of the subfamily Geotrupinae with revisions of the genera Bolbocerosoma, Eucanthus, Geotrupes and Peltotrupes (Scarabaeidae). Proc. U. S. Nat. Museum, 104 (3342): 151-319.

Peck, S. B. 1967a. The life cycle of the troglobitic catopid beetle Ptomaphagus loedingi. American Zoologist, 7: 809 (abstract).

Peck, S. B. 1967b. Trapping and the ecology of cave Ptomaphagus beetles (Catopidae). Bull. National Speleological Society, 29: 100 (abstract).

Peck, S. B. 1973. A systematic revision and the evolutionary biology of the Ptomaphagus (Adelops) beetles of North America (Coleoptera: Leiodidae: Catopinae) with emphasis on cave-inhabiting species. Bull. Mus. Comp. Zool. (Harvard Univ.), 145: 29-161,.

Poulson, T. L. and David C. Culver. 1969. Diversity in terrestrial cave communities. Ecology, 50: $153-158$.

Poulson, T. L. and W. B. White. 1969. The cave envireonment. Science, 165 (3897): 971-981. 